ELEVATION AND SUBSIDENCE.

Sir,-I have just seen the December Number of the Grocogical Magazine containing a short article called "The Pleistocene Geology of the Firth of 'Tay and the Elevation and Subsidence Question." The writer remarks on the depression of the land to a depth of at least 500 feet during the earlier part of the Glacial Period, and alds that, as the marine stratified deposits rest "upon the ground moraine of the ice-sheet," whatever this may mean, it is conclusively shown that when the sea sands were deposited, "the ice was very greatly reduced, bad retired from the coast-line, and possibly disappeared altogether." He further thinks it evident that this submergence was relatively short, and that a greater, which deposited an extensive raised plain, occurred "when the glaciers were in their final retreat," and deduces from these facts that "at any rate the Glacial and Post-Glacial history of Scotland gives no countenance to the theory," i.e. that additions of weight produce subsidence. Original observations of fact are valuable, and any inferences fairly deducible from such have a right to be tacked on, if the observer pleases; but in this case there do not appear to be any new facts quoted, and certainly none that justify any approximation to the sweeping assertion just cited. The continued depression of the land by the aceumulation of ice would naturally lead to encroachments of the sea, which would melt the ice and deposit on the top of the "ground moraine," if any existed, stratified sand, or mud. The Firth of Tay would, in fact, become a fiord. Why this replacement of ice by sea-water on an area should lead to the belief that the thickness of ice on adjacent and more elevated areas had diminished, I cannot think. Ice even in Greenland seldom reaches the sea-shore, except at the heads of fiords, while an accumulating ice-cap, such as the Vatna-jokul, which is 3000 miles in extent, might be exerting considerable influence in the direction of depression without coming near the sea. Not long since an equally valuable criticism was advanced, namely, that because elevation had commenced before the disappearance of the ice-sheet, it could not have been caused by it, as if an ice-cap of a thousand feet thickness or so would not get very sensibly lighter before it disappeared.

\title{
J. Starkie Gardner.
}

\section{ON PALAOCYCLUS FLETCHERI, EDW. H.}

Sir.-In the Quarterly Journ. Geol. Soc. for February, 1884, Prof. Duncan demurs as to the identity of Paleocyclus Fletcheri with Pholidophyllum tubulatum, Schlotheim (=Phol. (Cyathophyllum?) Lovéni, E. H.), chiefly on the ground that Prof. Duncan has never seen in English specimens a trace of the peculiar scaly coating, which covers the epitheca of Pholidophyllum. I have, amongst other specimens of this coral from Dudley, sent through the kindness of Mr. John Gray, of Hagley, two of the low depressed variety 
commonly called Palaocyclus Fletcheri. One of them so exactly resembles the figures $3,3 a$, on plate 57 of M. Edwards' British Fossil Corals, that it might well have been the original of that figure. Now on this, as well as on the other specimen mentioned, the epithecal scales are as plainly visible as on the Gotland specimens. I have not the least doubt that on closer examination more English specimens with scales in situ will turn up. In consequence of the fact now adduced, the assertions of Prof. Duncan cannot any longer be upheld. But even if the epithecal scales had not been found, there are such fundamental discrepancies in the intimate structure of Cyathophyllum and Pholidophyllum, as shown in the numerous figures of von Koch and even in my memoir. that it is inconceivable how anybody still can persist in placing Pal. Fletcheri or Phol. Loveni amongst the Cyathophylla.

I avail myself of this opportunity to correct some errors which have crept into Prof. Duncan's quotations of my paper, on pp. 176 and 177 of the Quart. Journ. Geol. Soc., and for which I am not responsible. In the translation of the generic description of Pholidophyllum, Prof. Duncan has the following passage: "Loculi filled with 'like-formed' stereoplasma, numerous in the midst of the coiral, most frequently in regular equidistant tabulæ." What this means I for one am unable to understand. According to the Swedish original there ought to stand: "Loculi filled with homogeneous stereoplasma, in the midst of the coral are numernus tabula, in most specimens regularly distantiated." This description covers the English specimens, as well as the Swerlish, North American and Russian ones, which I have examined. Further, Prof. Duncan has "Triplasma" instead of Tryplasma, "Scarithodes" (!) for Acanthodes, "Haliophyllum" for Heliophyllum, "Acanthocoenium" for Acanthoconium, Paleocyclus, "porcatus" for P. prencutus, etc.

As to the genus Palrocyclus of Milne-Edwards, it contains at least three generic types, viz. :

1. Paleocyclus sensu, pr. Type P. porpita, L., which probably only occurs in Gotland.

2. Pholidophyllum-Pal. Fletcheri.

3. Genus novum. Pal. rugosus, altogether differing from the former and pertaining to a special, as yet not defined genus.

The retaining of Palcooryclus as an independent genus with $P$. porpita as a type, does not imply that it must of necessity be kept amongst the Fungidæ. Already in 1865, I expressed my opinion that it was to be regarded as a Rugose, in my first paper on the operculated corals. The translation of this point in the GeoLoGICAL Magazine, Vol. III. p. 144, not being exact, I give anew from the original. "Its (= Pal. porpita) compact and solid structure, not perforated nor spongy as in the Fungide, its septa, which alternate with the exterior folds (costa), give it a place in the Zoantharia rugosa."

G. LindströM.

Royal Academy of Sweden, Stockholim. 